Pesq. Vet. Bras. 37(11):1220-1228, novembro 2017

DOI: $10.1590 / \mathrm{S} 0100-736 \mathrm{X} 2017001100006$

\title{
Aspectos macroscópicos e histológicos da cisticercose bovina ${ }^{1}$
}

\author{
Welden Panziera ${ }^{2}$, Andréia Vielmo ${ }^{2}$, Ronaldo M. Bianchi ${ }^{2}$, Caroline P. de Andrade ${ }^{2}$, \\ Saulo P. Pavarini², Luciana Sonne ${ }^{2}$, João F. Soares ${ }^{3}$ e David Driemeier ${ }^{2 *}$
}

\begin{abstract}
Panziera W., Vielmo A., Bianchi R.M., Andrade C.P., Pavarini S.P., Sonne L., Soares J.F. \& Driemeier D. 2017. [Macroscopic and histological findings of bovine cysticercosis.] Aspectos macroscópicos e histológicos da cisticercose bovina. Pesquisa Veterinária Brasileira 37(11):1220-1228. Setor de Patologia Veterinária, Faculdade de Veterinária, Universidade Federal do Rio Grande do Sul, Av. Bento Gonçalves 9090, Prédio 42505, Porto Alegre, RS 91540-000, Brazil. E-mail: davetpat@ufrgs.br

Bovine cysticercosis is an important zoonotic parasitic disease with high prevalence in several regions of Brazil. Considering the need of improvement of the accuracy of diagnosis of these lesions, as well as the difficulty of classification of the cysts, this study aimed to correlate gross and histopathological changes of bovine cysticercosis and to use polymerase chain reaction (PCR) as an aid in their identification. Cystic and nodular lesions from cattle, grossly compatible with cysticercosis, were sampled in slaughterhouses from Rio Grande do Sul State. Lesions were allotted in one of the following groups. Group 1: viable cysticercus; Group 2 (subdivided 2a e 2b): degenerating cysticercus with a potentially viable scolex; and Group 3: dead cysticercus (mineralized). The gross and microscopic aspects of every cysticerci of each group were compared. Two hundred and thirty two cysts and nodules compatible with cysticercus were sampled from 127 bovine. Twenty six of those lesions were tested with PCR. Out of 127 cattle, 46 (36.2\%) had more than one cyst and the remaining 81 (63.8\%) had on cyst each. Myocardium was the most frequently involved anatomical site (55.9\%), followed by masseter muscle (22.8\%). When there was more than one organ involved in the same bovine, myocardium a master muscle sum up 11 cases (8.6\%). In general, the average of cysticercosis frequency was $10-15 \%$. However the average in some cattle lots was in excess of $50 \%, 80 \%$ and $90 \%$. Morphologically, 232 cysticerci were classified in three groups. In Group 1, 23 cysticerci (9.9\%) were considered viable and were characterized by cysts of translucent or slightly opaque wall, containing clear and a white point (scolex) within the cyst. Histologically, the cysts consisted of a membrane from which a scolex of Taenia saginata invaginated. One hundred and fifty six cysts (67.2\%) were allotted in Group 2; grossly these cysts revealed two different morphological patterns. In $111(71.1 \%$ ) cases of Group 2 (Group 2a) nodular caseous lesions were observed. Histologically, the cysts were characterized by nodules consisting by a central area containing the scolex and membrane, both degenerated, and caseous necrosis. In the remaining 45 (28.9\%) cases of Group 2 (Group 2b), lesions were also caseous; however, at cut surface the cysts had a central hole amidst the caseous material. The microscopic aspect of the 45 cysts included in the second was similar to that of the first pattern. However in eight (17.8\%) of the 45 cysts only a viable parasitic membrane was observed and in one cyst the membrane and viable scolex were observed. In the remaining 36 cases (80\%), the cysts consisted of a central area containing both degenerated membrane and scolex, and caseous necrosis. In Group 3, 53 dead cysts (mineralized) (22.9\%) were found among the total of 232 cysts. The
\end{abstract}

\footnotetext{
${ }^{1}$ Recebido em 20 de fevereiro de 2017.

Aceito para publicação em 28 de março de 2017.

${ }^{2}$ Setor de Patologia Veterinária, Departamento de Patologia Clínica Veterinária, Faculdade de Veterinária, Universidade Federal do Rio Grande do Sul (UFRGS), Avenida Bento Gonçalves 9090, Prédio 42505,
}

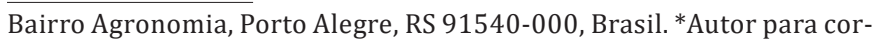
respondência: davetpat@ufrgs.br

${ }^{3}$ Laboratório de Protozoologia, Departamento de Patologia Clínica Veterinária, Faculdade de Veterinária, UFRGS, Av. Bento Gonçalves 9090, Prédio 42505, Porto Alegre, RS 91540-000, Brasil. 
gross aspect of these cysticerci was characterized by yellow form nodules which crumbled when cut. Histologically nodules were observed with marked central area of mineralization surrounded by granulomatous inflammatory response. Twenty four of the twenty cysts examined by PCR were positive for Cysticercus bovis and two of them were negative. One of the negatives was part of Group 2 (degenerated cysts) and the other one of the Group 3 (dead mineralized cysts). The correlation between gross and microscopic aspects of the second morphologic aspect of the Group 2 demonstrated that this subset represents a major complicating factor in interpretation, since a large number of these cysts reveal characteristics of viability. Grossly, these cysticerci might be identified when cut, since a hole in the central area will be observed aiding in recognizing his lesions.

INDEX TERMS: Cattle diseases, parasitic diseases, public health, bovine cysticercosis, Cysticercus bovis, Taenia saginata, lesion patterns.

RESUMO.- Cisticercose bovina é uma importante doença parasitária de caráter zoonótico, com elevada ocorrência em algumas regiões do Brasil. Considerando a possibilidade de erro na identificação das lesões, bem como a dificuldade de classificação dos cistos e a necessidade de melhorar o diagnóstico, o objetivo desse trabalho foi caracterizar e correlacionar as lesões macroscópicas e microscópicas da cisticercose bovina, além de utilizar a técnica da PCR para auxiliar na identificação do agente. Amostras de lesões císticas e nodulares de bovinos, compatíveis macroscopicamente com cisticercose, foram coletadas em abatedouros frigoríficos do Estado do Rio Grande do Sul. Os cistos foram divididos em três grupos: Grupo 1, cisticercos vivos (viáveis); Grupo 2 (subdividido em $2 \mathrm{a}$ e $2 \mathrm{~b}$ ), cisticercos degenerados com potencial escólex viável; e Grupo 3 cisticercos mortos (mineralizados). Após a obtenção das lâminas histológicas dos cisticercos de cada grupo, foi realizada a correlação macroscópica e microscópica. Para a realização da técnica da PCR foram utilizadas lesões císticas de 26 bovinos. Foram analisados cisticercos de 127 bovinos, totalizando 232 cistos. Dos 127, 46 bovinos (36,2\%) apresentaram mais de um cisticerco e $81(63,8 \%)$ um cisticerco cada. Em relação a localização anatômica dos cistos, o coração demonstrou o maior envolvimento $(55,9 \%)$, seguido do músculo masseter $(22,8 \%)$. Quando houve o envolvimento de dois órgãos em um mesmo bovino, coração e músculo masseter juntos, totalizaram 11 casos $(8,6 \%)$. De maneira geral a média da frequência de cisticercose foi de $10 \%$ a $15 \%$ de bovinos acometidos por lote. Entretanto, a média isolada de alguns lotes demonstrou condenações acima de 50\%, 80\% e 90\%. Morfologicamente, os 232 cisticercos foram classificados dentro de três grupos. No Grupo 1, 23 cistos (9,9\%) foram considerados como vivos (viáveis), e eram caracterizados por lesões císticas com parede translúcida ou levemente opaca, contendo líquido claro e um ponto esbranquiçado no interior (escólex). Na histologia, os cistos eram compostos por uma membrana de onde invaginava um escólex de Taenia saginata. No segundo grupo (Grupo 2), foram incluídos 156 $(67,2 \%)$ cisticercos degenerados com potencial escólex viável e macroscopicamente os cistos demonstraram dois padrões morfológicos distintos. No primeiro deles (Grupo 2a), visualizado em 111 casos (71,1\%), observaram-se lesões nodulares com aspecto caseoso. Microscopicamente, os cistos caracterizavam-se por formações nodulares compostas por área central contendo escólex e membrana, ambos degenerados, e necrose caseosa. No segundo padrão (Grupo 2b), observado em 45 cisticercos (28,9\%), as lesões também eram caseosas, entretanto ao corte os cistos demonstravam na área central um orifício em meio ao material caseoso. Os aspectos microscópicos dos 45 cistos incluídos no segundo padrão macroscópico assemelhavam-se aos cisticercos do primeiro padrão. Entretanto, oito cistos $(17,8 \%)$ demonstraram somente a membrana parasitária viável e em um cisto notou-se a membrana com o escólex viável. No restante dos 36 cistos (80\%), observou-se área central contendo escólex e membrana, ambos degenerados, e necrose caseosa. No terceiro grupo de classificação morfológica dos cisticercos (Grupo 3), foram inseridos os cistos mineralizados (mortos), totalizando 53 cistos (22,9\%). 0 aspecto macroscópico desses cisticercos caracterizava-se por lesões nodulares, amarelas, firmes ao corte, que se fragmentavam. Histologicamente observaram-se formações nodulares com área central de acentuada mineralização, rodeadas por infiltrado inflamatório granulomatoso. Dos 127 bovinos, foi realizado PCR a partir do DNA extraído dos cisticercos de 26 bovinos, no qual 24 foram positivos para cisticercose. Em relação aos dois cisticercos negativos, um deles fazia parte do Grupo 2a e o outro do Grupo 3. A correlação entre os aspectos macroscópicos e microscópicos do segundo padrão morfológico observado dentro do Grupo 2, demonstrou que esse subgrupo representa o maior problema na interpretação, pois alguns cistos apresentaram características de viabilidade. Macroscopicamente esses cisticercos podem ser identificados quando cortados, porque possuem um orifício na área central que pode auxiliar no diagnóstico.

TERMOS DE INDEXAÇÃO: Doenças de bovinos, doenças parasitárias, saúde pública, cisticercose bovina, Cysticercus bovis, Taenia saginata, padrões de lesões da cisticercose.

\section{INTRODUÇÃO}

Cisticercose é uma importante doença parasitária de caráter zoonótico, com elevada ocorrência em algumas regiões do Brasil e representa um grave problema socioeconômico e de saúde pública (Rossi et al. 2014). No ciclo da cisticercose bovina, Cysticercus bovis constitui o estágio larval da Taenia saginata. 0 bovino é o hospedeiro intermediário e o homem o hospedeiro definitivo. Nesse ciclo, os humanos se contaminam ingerindo carne bovina crua (com o cisticerco) ou que não atingiu $65^{\circ} \mathrm{C}$ no seu processo de cocção (mal passada), enquanto que os bovinos se infectam ao consumirem água ou pastagem contaminadas com ovos viáveis 
do parasita, ou por qualquer outro modo que leve à ingestão desses ovos, mesmo que esporádico e involuntário. Os ovos são eliminados nas fezes dos humanos portadores de Taenia saginata e podem sobreviver na pastagem durante vários meses (Urquhart et al. 1996, Rey 2013, Bowman 2014). A cisticercose bovina provoca condenações no exame post mortem de carcaças e órgãos em abatedouros frigoríficos, ocasionando relevantes perdas econômicas para produtores e indústria. Essas perdas estão relacionadas, principalmente, à limitação da comercialização dos produtos ao mercado externo, gastos com tratamento pelo frio e gastos com tratamento parasitário (Rossi et al. 2014).

No Brasil, para o diagnóstico da cisticercose bovina durante o exame post mortem, o serviço veterinário oficial avalia as características morfológicas macroscópicas dos cisticercos classificando-os como vivos ou mineralizados. Este tipo de classificação obedece a procedimentos padronizados de acordo com o artigo 185 do Regulamento da Inspeção Industrial e Sanitária de Produtos de Origem Animal -RIISPOA (Brasil 2017). Não há muita dificuldade para o diagnóstico macroscópico de cisticercose quando o parasita está vivo (íntegro). Entretanto, o diagnóstico pode ser difícil no caso em que o metacestódeo esteja morto e mineralizado. Nestas circunstâncias, o apoio do exame histopatológico pode ser de grande valia na diferenciação das lesões (Costa et al. 2006).

0 cisticerco vivo designa a condição de viabilidade infecciosa do metacestódeo e a denominação cisticerco mineralizado implica em sua incapacidade infecciosa. Mas é evidente que existem outras etapas intermediárias, as quais são de difíceis interpretações (Biondi et al. 2000). Dúvidas quanto a viabilidade do cisticerco na inspeção post mortem, em especial nessas fases intermediárias, podem acarretar equívocos no diagnóstico de cisticercose e consequentemente condenações errôneas e destinos incorretos de carcaças e órgãos. Considerando essa possibilidade e a necessidade de melhorar o diagnóstico, o objetivo desse trabalho foi caracterizar e correlacionar as lesões macroscópicas e microscópicas da cisticercose bovina, além de utilizar a técnica de PCR (reação em cadeia da polimerase) para auxiliar na sua identificação. Assim o estudo tem o intuito de que a descrição das características macroscópicas e microscópicas possa fomentar a decisão dos inspetores no exame post mortem e assim diminuir os custos com condenações errôneas, bem como, auxiliar na manutenção da inocuidade do produto minimizando os riscos de infecção pelo consumo.

\section{MATERIAL E MÉTODOS}

Amostras de lesões císticas e nodulares observadas em músculos esqueléticos, miocárdio e fígado de bovinos, compatíveis macroscopicamente com cisticercose, foram coletadas durante quatro visitas a diferentes abatedouros frigoríficos do Estado do Rio Grande do Sul. As lesões eram provenientes de bovinos abatidos nos municípios de Santa Maria, Farroupilha, Montenegro e Vacaria. No município de Santa Maria, o estabelecimento era fiscalizado pelo Serviço de Inspeção Federal (SIF), enquanto que nos demais municípios pelo serviço de inspeção Estadual (Coordenadoria de Inspeção Industrial e Sanitária dos Produtos de Origem Animal [CISPOA]). 0 material foi coletado no Departamento de Inspeção Final de cada abatedouro, identificado e fotografado.
Os cisticercos colhidos foram fixados em formol a $10 \%$, clivados, processados rotineiramente para histologia e corados pela técnica de hematoxilina e eosina (HE). Macroscopicamente, os cistos foram divididos em três grupos: Grupo 1, cisticercos vivos (viáveis); Grupo 2 (subdividido em 2a e 2b), cisticercos degenerados com potencial escólex viável; e Grupo 3, cisticercos mortos (mineralizados). Após a obtenção das lâminas histológicas dos cisticercos de cada grupo, foi realizada a correlação macroscópica e microscópica, com o auxílio das fotos do aspecto macroscópico de cada cisto. Para a realização da técnica da PCR foi utilizado o DNA extraído de lesões císticas de 26 bovinos. Os primers usados nesse estudo amplificam um fragmento de $807 \mathrm{pb}$ das regiões dos genes 18S e 28S RNA ribossomal de Taenia saginata. Os primers utilizados na reação de PCR foram: BD1 forward (5'-GTCGTAACAAGGTTTCCGT-3') e TSS1 reverso (5'-ATATGCTTAAGTTCAGCGGGTAATC-3'). As condições da PCR estão descritas de acordo com Narankhajid et al. (2007).

\section{RESULTADOS}

Foram analisados cisticercos de 127 bovinos, totalizando 232 cistos. Quarenta e seis bovinos apresentaram mais de um cisticerco, no qual 27 bovinos $(21,3 \%)$ demonstraram dois cisticercos; cinco bovinos $(3,9 \%)$ três cisticercos; cinco bovinos $(3,9 \%)$ quatro cisticercos; quatro bovinos $(3,1 \%)$ cinco cisticercos; três bovinos $(2,3 \%)$ seis cisticercos; um bovino $(0,8 \%)$ sete cisticercos; e um único bovino $(0,8 \%)$ apresentou 24 cisticercos. Os demais bovinos $(63,8 \%)$ apresentaram um cisticerco cada. Em relação a localização anatômica dos cistos de Cysticercus bovis, quando considerado somente um órgão acometido em cada bovino, o coração demonstrou o maior envolvimento $(55,9 \%)$, seguido do músculo masseter $(22,8 \%)$, músculo peitoral $(3,1 \%)$, diafragma $(2,4 \%)$ e músculo da língua $(2,4 \%)$. Quando houve o envolvimento de dois órgãos em um mesmo bovino, as prevalências foram as seguintes: coração e músculo masseter (8,6\%); coração e língua (1,6\%); coração e fígado $(0,8 \%)$; e coração e diafragma $(0,8 \%)$. Um bovino $(0,8 \%)$ tinha cistos no coração, músculo masseter e músculo da língua; e um único bovino $(0,8 \%)$ apresentou cistos no coração, músculo masseter, músculo da língua, diafragma e músculo peitoral, totalizando 24 cistos no mesmo bovino.

Observou-se alta frequência de cisticercose em alguns lotes de bovinos. De maneira geral, a média foi de $10 \%$ a $15 \%$ de bovinos acometidos por lote. Entretanto, em alguns lotes houve condenações acima de 50\%, 80\% e 90\%. Os lotes com alta infecção de cisticercose eram oriundos de propriedades com criações de bovinos nos sistemas intensivos (confinados) ou extensivos (criação à campo), de diferentes regiões do Estado do Rio Grande do Sul. Uma das propriedades com altos índices de condenações foi visitada, no qual foi possível constatar problemas de saneamento básico e contaminação do confinamento por dejetos de humanos com consequente contato dos bovinos. Em outras propriedades com problemas, havia relatos de funcionários que foram realizar serviços eventuais (como cerca, por exemplo) e consequentemente contaminaram o campo após eliminação de dejetos.

Morfologicamente os 232 cisticercos foram classificados dentro de três grupos: Grupo 1 - cisticercos vivos (viáveis); Grupo 2 (subdividido 2a e 2b) - cisticercos degene- 
rados com potencial escólex viável; e Grupo 3 - cisticercos mineralizados (mortos). No primeiro grupo (Grupo 1), 23 cisticercos $(9,9 \%)$ foram considerados como vivos (viáveis), e eram caracterizados por lesões císticas com parede translúcida ou levemente opaca, contendo líquido claro e um ponto esbranquiçado no interior (escólex) (Figs. 1A, $1 B$ e 1C). Na histologia, os cistos eram compostos por uma membrana fracamente eosinofílica, que apresentava numerosas microvilosidades (microtríquias). Da porção interna da membrana invaginava um escólex esférico de Taenia saginata com aproximadamente $1 \mathrm{~mm}$ de diâmetro (Fig.1D). O escólex (Fig.1E) apresentava tegumento de revestimento, era acelomado e desprovido de trato digestivo. Foram observadas numerosas e diminutas estruturas basofílicas ovais distribuídas pelo parênquima do parasita (corpúsculos calcários). Em algumas seções verificaram-se estruturas circulares compostas por músculos com fibras em arranjo radial (ventosas). Adjacente à parede do cisto observou-se leve a moderado infiltrado inflamatório de histiócitos dispostos em paliçada, linfócitos, plasmócitos, macrófagos e em menor quantidade eosinófilos (Fig.1F).

No segundo grupo (Grupo 2) foram incluídos 156 $(67,2 \%)$ cisticercos degenerados com potencial escólex viável. Esse grupo foi o mais representativo. Macroscopicamente, os cistos demonstraram dois padrões morfoló- gicos distintos. No primeiro deles (Grupo 2a), visualizado em 111 casos $(71,1 \%)$, observaram-se lesões nodulares que variavam de 1 a $4 \mathrm{~cm}$ de diâmetro, de coloração verde, amarela ou branca (Fig.2A). Ao corte dessas estruturas císticas, observou-se material caseoso verde ou amarelo, envolto por uma cápsula fibrosa (Fig.2B). Microscopicamente, todos os cistos desse subgrupo caracterizavam-se por formações nodulares compostas por área central contendo escólex e membrana, ambos degenerados, e necrose caseosa com focos de mineralização com intensidade variável, rodeados por acentuado infiltrado inflamatório de histiócitos dispostos em paliçada, macrófagos epitelioides, com ocasionais células gigantes multinucleadas e mais externamente linfócitos, plasmócitos, eosinófilos e proliferação de tecido fibrovascular (Fig.2C e 2D). Desses, seis casos $(6 / 111[5,4 \%])$ foi possível identificar numerosas estruturas basofílicas ovais (corpúsculos calcários).

No segundo padrão macroscópico (Grupo 2b), observado em 45 cisticercos (28,9\%), as lesões também eram nodulares, com 1 a 4cm de diâmetro, amarelas ou verdes, por vezes com áreas avermelhadas (Fig.3A) e circundadas por cápsula de tecido fibroso, que em alguns casos era espessa. Ao corte dos cistos observava-se um orifício central em meio ao material caseoso (Fig.3B e 3C). Os aspectos microscópicos observados nos 45 cistos do Grupo 2b assemelha-
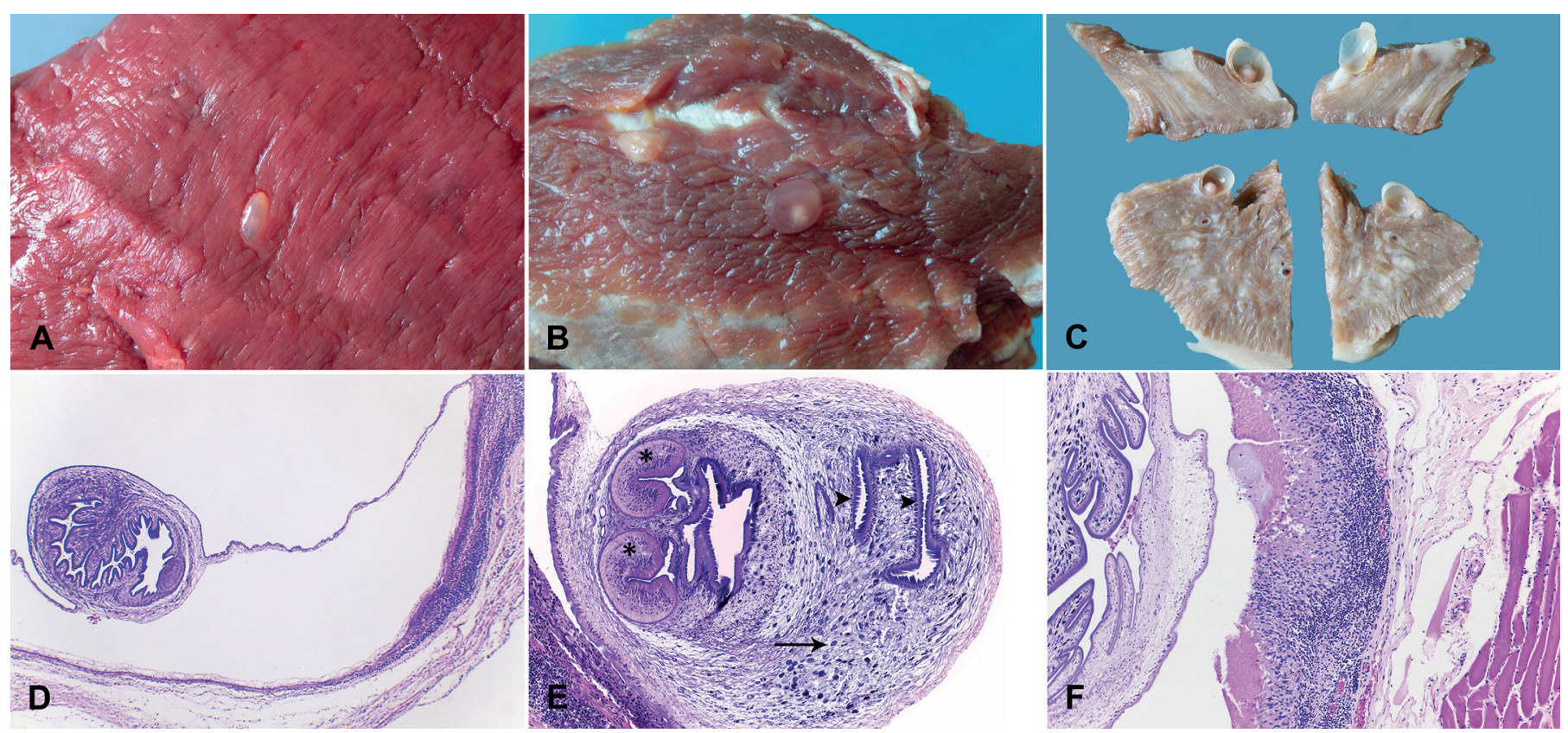

Fig.1. Aspectos macroscópicos e histológicos da cisticercose bovina. Grupo 1. (A) Lesão vesicular no coração com parede levemente opaca. (B) Músculo masseter. Cisticerco com membrana translúcida preenchido por líquido claro. No interior do cisto há uma pequena estrutura brancacenta (escólex). (C) Superfície de corte de dois cisticercos viáveis fixados em formol observados no músculo esquelético e língua. Note que os cistos são revestidos por uma delgada membrana e no interior são visualizadas estruturas brancacentas e arredondadas, caracterizando os escólices. (D) Aspecto histológico de um cisto de Cysticercus bovis viável no coração. Há um escólex invaginando a partir da membrana parasitária. HE, obj.4x. (E) Escólex acelomado de $C$. bovis caracterizado pela ausência de trato digestivo e contendo numerosas e diminutas estruturas basofílicas ovais (corpos calcários) distribuídas aleatoriamente pelo parênquima (seta estreita). Observe também tegumento (cabeça de seta) e duas estruturas circulares compostas por músculos com fibras em arranjo radial (ventosas [asterisco]). HE, obj.20x. (F) Imagem aproximada demonstrando a reação inflamatória do hospedeiro adjacente a parede do cisto de $C$. bovis. À esquerda da imagem observa-se parte do escólex com a membrana, contendo em seu interior tegumento e os corpúsculos calcários. Na porção central da foto nota-se infiltrado inflamatório de macrófagos dispostos em paliçada, macrófagos epitelioides e linfócitos, além de discreta proliferação de tecido fibroso e à direita da imagem músculo esquelético. HE, obj.20x. 


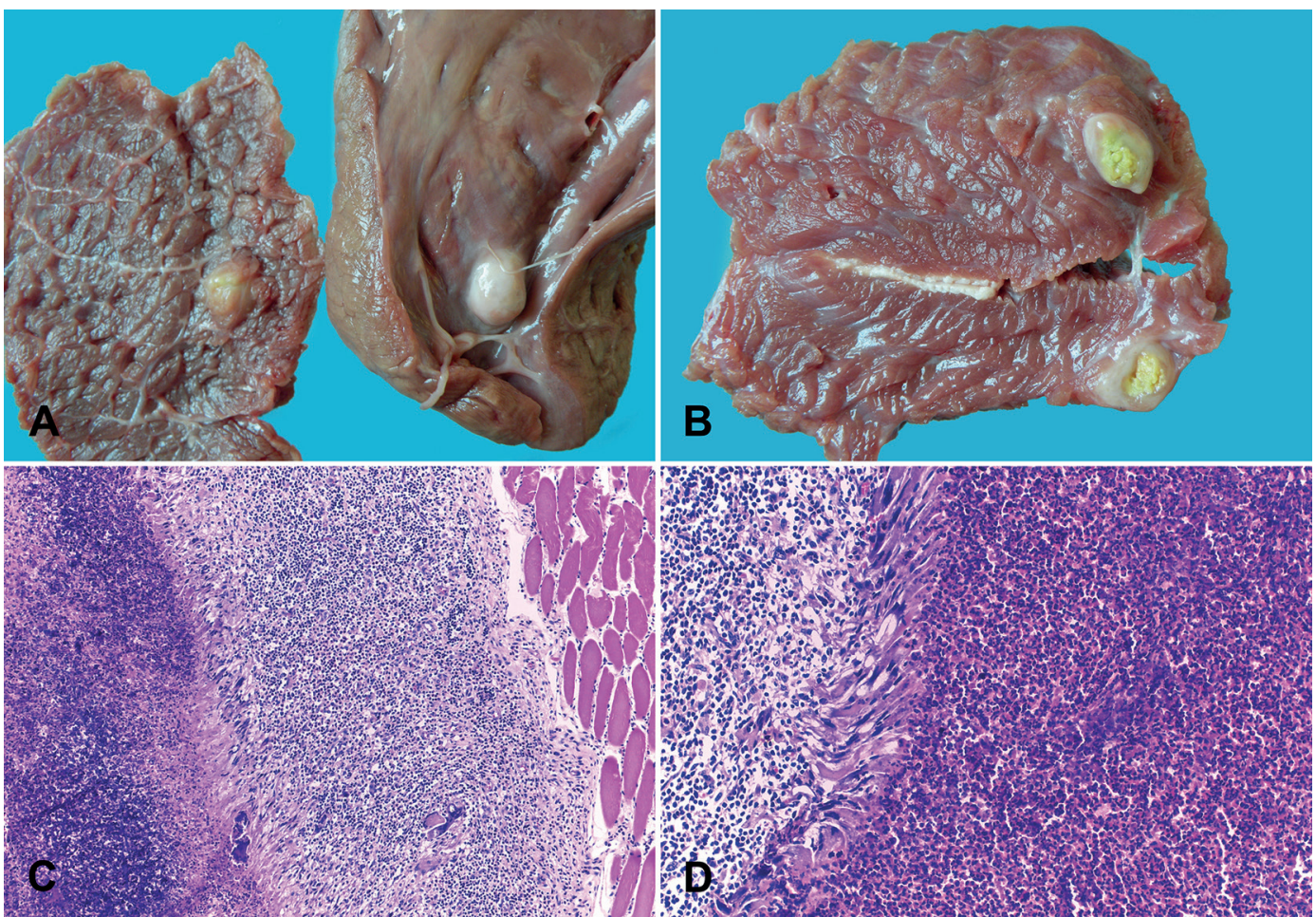

Fig.2. Aspectos macroscópicos e histológicos da cisticercose bovina. Grupo 2a. (A) Lesões nodulares, de coloração branca e amarela no músculo masseter e coração. (B) Superfície de corte de um cisto degenerado no músculo masseter. Observa-se material caseoso amarelo e friável envolto por cápsula fibrosa. (C) Aspecto histológico de um cisticerco degenerado no músculo masseter. A área central do cisto é composta por necrose caseosa contendo grande quantidade de debris celulares, envolta por acentuado infiltrado inflamatório de histiócitos dispostos em paliçada. Mais externamente há infiltrado mononuclear, macrófagos epitelioides, além de ocasionais células gigantes multinucleadas e proliferação de tecido fibrovascular. HE, obj.10x. (D) Imagem mais aproximada da Figura C, demonstrando com maior detalhe a necrose caseosa central e infiltrado inflamatório adjacente de histiócitos dispostos em paliçada, linfócitos, plasmócitos, macrófagos epitelioides e ocasionais células gigantes multinucleadas. HE, obj.20x.

vam-se aos achados microscópicos dos cisticercos incluídos no primeiro padrão (Grupo 2A). Em 36 casos (80\%), os cistos eram compostos por área central contendo o escólex e a membrana, ambos degenerados, e necrose caseosa com áreas de mineralização, e infiltrado inflamatório circunjacente, semelhante ao descrito anteriormente (Fig.3D). Entretanto, oito cistos $(17,8 \%)$ demonstraram somente a membrana parasitária viável (Fig.3E) e em um cisto, observado no fígado, havia a membrana com o escólex viável (Fig.3F). Essas estruturas parasitárias eram circundadas por moderado a acentuado infiltrado inflamatório de histiócitos dispostos em paliçada, macrófagos epitelioides, com ocasionais células gigantes e mais externamente linfócitos, plasmócitos, eosinófilos e proliferação de tecido fibrovascular.

No terceiro grupo de classificação morfológica dos cisticercos (Grupo 3), foram inseridos os cistos mineralizados (mortos), totalizando 53 casos $(22,9 \%)$. 0 aspecto macroscópico desses cisticercos caracterizava-se por lesões nodulares, amarelas, variando de $1-3 \mathrm{~cm}$ de diâmetro (Fig.4A). Ao corte, as estruturas císticas eram firmes e fragmentavam-se, formando pequenas concreções duras e amareladas (Fig.4B). Histologicamente observaram-se formações nodulares com área central de acentuada mineralização, rodeadas por moderado a acentuado infiltrado inflamatório de histiócitos dispostos em paliçada, macrófagos epitelioides, com ocasionais células gigantes multinucleadas e mais externamente linfócitos, plasmócitos, eosinófilos e proliferação de tecido fibroso (Figs. 4C e 4D). Em sete dos 53 cistos $(13,2 \%)$, havia corpúsculos calcários em meio à mineralização.

Foi realizado PCR dos cistos de 26 dos 127 bovinos. Vinte e quatro foram positivos para Cysticercus bovis e somente dois foram negativos. Um dos cisticercos negativos fazia parte do Grupo 2a e o outro foi classificado como do Grupo 3.

Duas estruturas nodulares pequenas coletadas na língua de dois bovinos foram excluídas do estudo, pois histologicamente observou-se piogranulomas com formação de Splendore Hoeppli, caracterizando casos de actinobacilose.

\section{DISCUSSÃO}

A ocorrência da cisticercose bovina geralmente é conhecida através dos informes divulgados pelos Serviços de Inspeção Sanitária municipais, estaduais ou federais, o que permite o conhecimento da intensidade da infecção e os locais com maior diagnóstico dessa doença. Dados do presente estudo demonstram uma alta prevalência de cisticercose em alguns lotes de bovinos coletados. No Brasil, dependendo da região, a cisticercose bovina é considerada umas das principais ou a principal doença parasitária diagnosticada no exame post mortem em bovinos (Pfuetzenreiter \& Ávila-Pires 2000, Costa et al. 2006, 2012, Tessele et al. 2013). As ocorrências regionais em nosso país registraram percentu- 
ais de 4\%-45\% nas propriedades rurais, com alguns lotes chegando próximo a $100 \%$, semelhante ao observado neste estudo. Prevalências de cisticercose acima de 10\% são extremamente comuns no Brasil. Assim, fica evidente seu caráter enzoótico e, por vezes, epizoótico em determinadas regiões, o que a torna um grave problema socioeconômico e de saúde pública (Costa et al. 2012).

A falta de educação sanitária da população que vive na zona rural e a deficiência de saneamento básico constituem os principais fatores de risco para o desenvolvimento do ciclo biológico da cisticercose bovina (Urquhart et al. 1996, Rey 2013). Esses aspectos epidemiológicos puderam ser observados nas propriedades rurais que apresentaram lotes com alta incidência de cisticercose neste estudo. Nesses estabelecimentos havia a contaminação da água e pastagem dos bovinos com dejetos humanos. A falta de fossas ou destino correto de esgoto em algumas áreas favorece a contaminação ambiental, sendo comuns os casos em que os bovinos acabam ingerindo involuntariamente fezes humanas (Rossi et al. 2014). Uma pessoa infectada elimina milhões de ovos por dia, livres nas fezes ou em proglótides. Cada proglótide contém cerca de 80.000 a 250.000 ovos que podem sobreviver na pastagem por vários meses (Urquhart et al. 1996, Rey 2013). A contaminação pode ocorrer também em propriedades banhadas por rios e córregos que cruzam nas proximidades de cidades ou estabelecimentos vizinhos contaminados. A água pode transportar os ovos da tênia por longas distâncias, sendo essa dispersão grandemente favorecida pelos rios, além de ocorrer maior viabilidade dos ovos em meio aquático (Rossi et al. 2014). Esses dados justificariam a alta incidência de cisticercose em estabelecimentos com ausência de saneamento básico.

Propriedades com criações intensivas e extensivas apresentaram elevadas taxas de condenações por cisticercose nesse estudo. Apesar de bovinos confinados possuírem maior incidência da doença (McAninch 1974, Bundza et al. 1988, Borman-Eby et al. 1994), bovinos criados extensivamente também podem apresentar infecções elevadas, caso estejam presentes alguns dos principais fatores predisponentes previamente discutidos.

Existe uma grande disparidade na literatura quanto aos locais de predileção dos cistos de Cysticercus bovis, porém, para a maioria dos autores, os metacestódeos são encontrados, principalmente, nos músculos mais irrigados, notadamente músculos mastigatórios e coração (Maxie \& Robinson 2007, Costa et al. 2012, Tessele et al. 2013, Cooper \& Valentine 2016), como demonstrado em nosso estudo (aproximadamente 85\% dos casos). Essas divergências sobre a distribuição dos cisticercos nos diferentes sítios anatômicos podem ser decorrentes de diversos fatores, como estudos realizados com populações grandes, porém de áreas geográficas diferentes, a habilidade e critério do
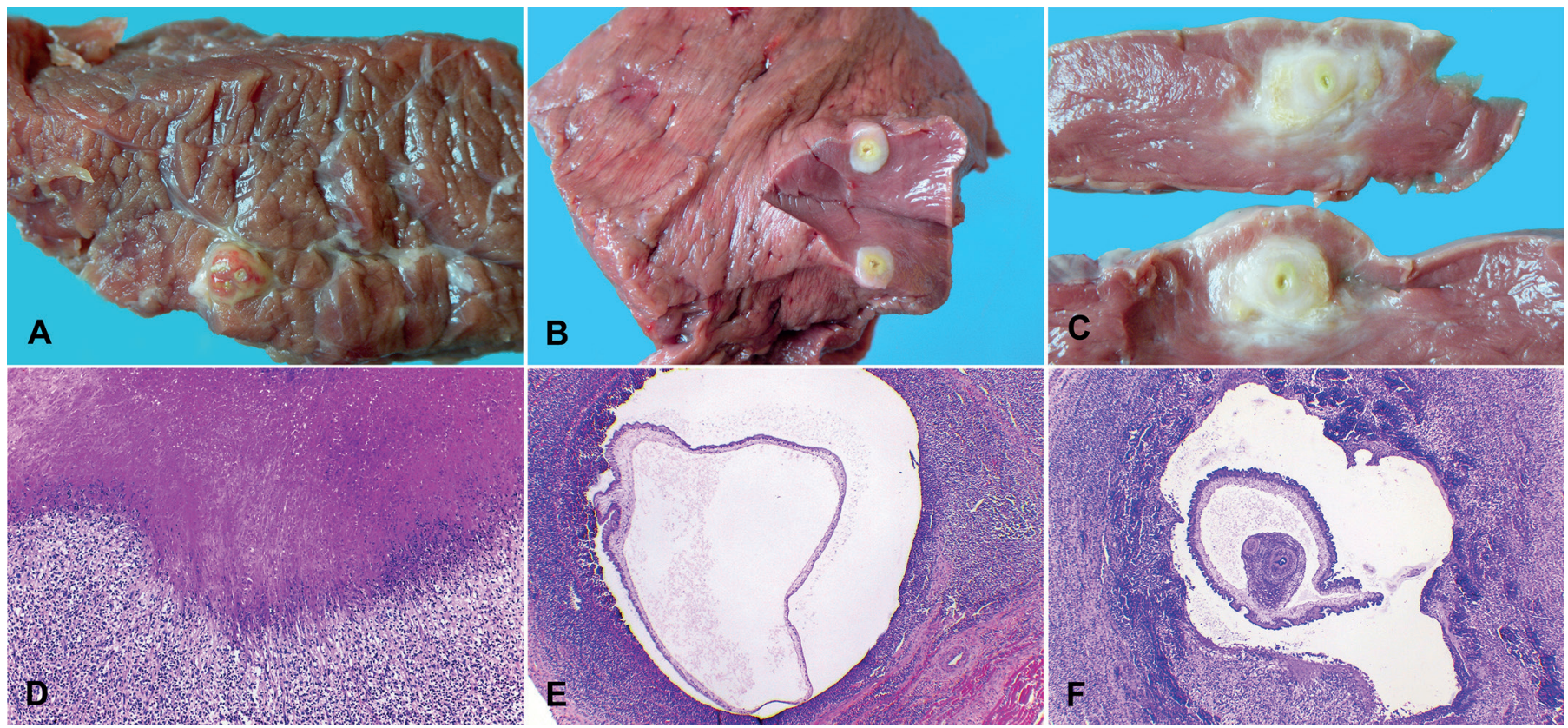

Fig.3. Aspectos macroscópicos e histológicos da cisticercose bovina. Grupo 2b. (A) Apresentação macroscópica de um cisticerco degenerado com potencial escólex viável no músculo peitoral. Note que a lesão é nodular, de superfície arredondada e de coloração amarela com áreas avermelhadas. (B) Superfície de corte de um cisticerco do Grupo 2 b visualizado no coração. Observe que na área central há um orifício em meio à necrose caseosa. Perifericamente ao material caseoso há uma cápsula fibrosa. (C) Superfície de corte de outro cisticerco observado no coração. Note nessa imagem que na área central também pode ser visualizado um orifício. Nesse caso a cápsula fibrosa é mais proeminente quando comparado com o cisto da figura anterior. (D) Histologia de um cisticerco não viável, com área central de necrose caseosa de coloração eosinofílica circundada por acentuado infiltrado inflamatório de histiócitos dispostos em paliçada e infiltrado predominantemente mononuclear na periferia. HE, obj. 10x. (E) Aspecto histológico de um cisticerco viável na musculatura esquelética. Nessa imagem, note a presença da membrana parasitária íntegra de C. bovis, sem o escólex. Adjacente ao cisto há acentuado infiltrado inflamatório, além de proliferação de tecido fibroso. HE, obj.10x. (F) Cisticerco viável observado no fígado. Nesse corte histológico a membrana e o escólex, ambos viáveis, estavam presentes e denotou a integridade e viabilidade desse cisticerco. Perifericamente, há acentuado infiltrado inflamatório granulomatoso e áreas de mineralização. HE, obj.10x. 


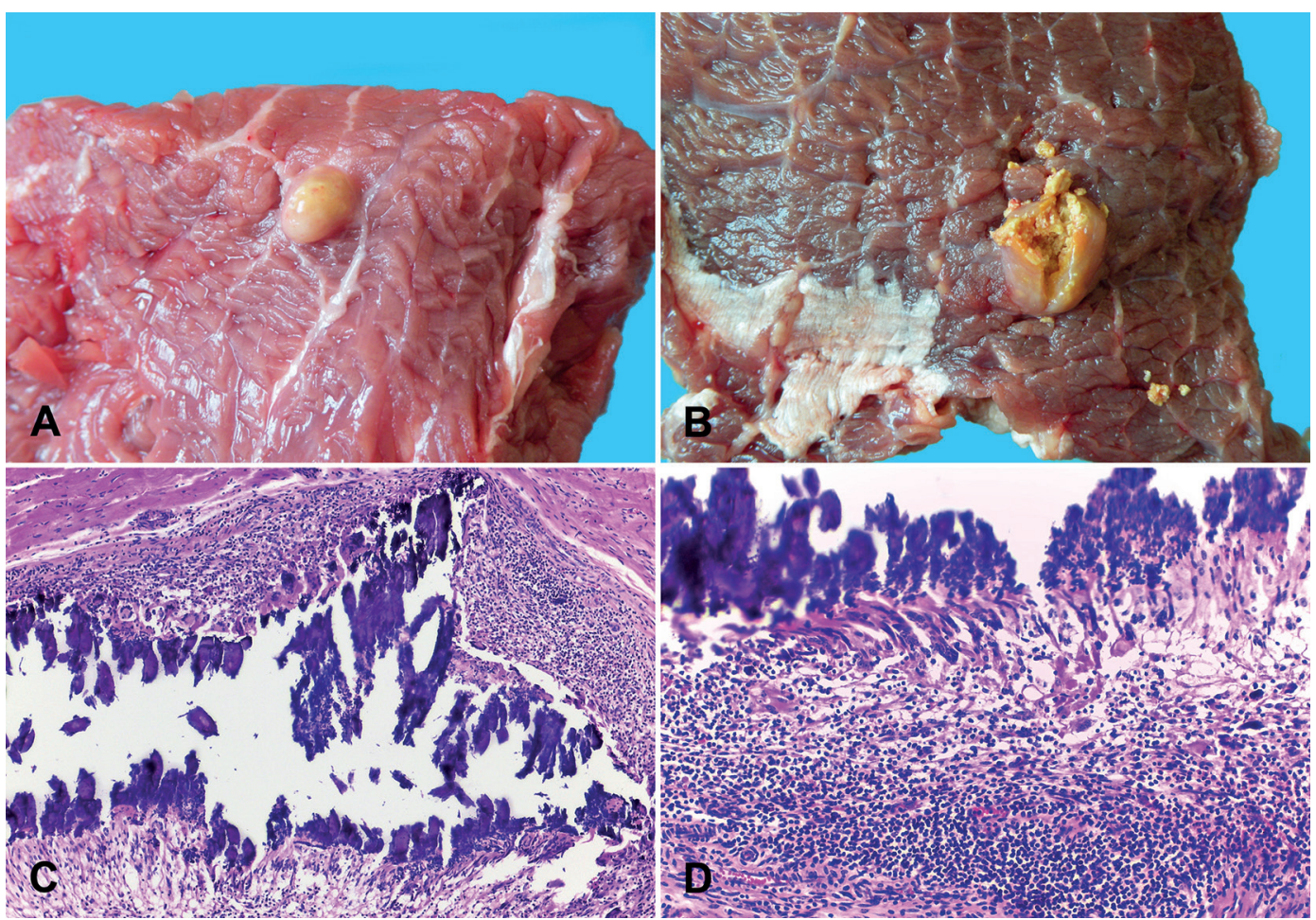

Fig.4. Aspectos macroscópicos e histológicos da cisticercose bovina. Grupo 3. (A) Cisticerco mineralizado não cortado no músculo masseter. Observa-se lesão nodular amarela de superfície lisa e arredondada. (B) Cisto de C. bovis mineralizado no músculo masseter cortado ao meio, no qual evidencia-se conteúdo amarelo e fragmentado. (C) Histologia de um cisticerco mineralizado no coração. Observe que a área central cística é composta por acentuada mineralização, circundada por marcado infiltrado inflamatório granulomatoso. HE, obj.10x. (D) Imagem mais aproximada da figura C demonstrando mineralização central e infiltrado inflamatório adjacente de histiócitos dispostos em paliçada. Observa-se ainda, mais externamente, infiltrado de linfócitos, plasmócitos, macrófagos epitelioides e ocasionais células gigantes multinucleadas, além de fibrose. HE, obj.20x.

inspetor e a não padronização das técnicas. Embora o envolvimento do diafragma (4\%) e fígado $(0,8 \%)$ não tenha sido expressivo nesse estudo, quando comparadas aos demais órgãos, é de grande importância suas inspeções nas linhas de rotina dos abatedouros, pois esses órgãos devem ser considerados como potenciais locais anatômicos de cisticercose. Cabe ressaltar, que a forma larvar começa a ser macroscopicamente visível cerca de duas semanas após a infecção, mas não é infectante para o homem antes de 12 semanas. A longevidade dos cisticercos varia de semanas a anos (Urquhart et al. 1996, Rey 2013). Estima-se que aos nove meses, a maioria dos cisticercos já morreu e mineralizou, mas em função da idade dos bovinos, a sobrevida e a longevidade das larvas podem ser prolongadas (Rey 2013).

Morfologicamente observaram-se três apresentações distintas de cisticercos nesse trabalho, no qual sugere-se uma classificação macroscópica simples dos cistos em três grupos, que incluem: cisticercos vivos (viáveis) (Grupo 1), cisticercos degenerados com potencial escólex viável (Grupo 2 [2a e 2b]) e cisticercos mineralizados (mortos) (Grupo 3). Optou-se por essa divisão, pois após o acompanhamento da rotina de inspeção dos médicos veterinários e inspetores oficiais notou-se que não há muita dificuldade para o diagnóstico macroscópico de $C$. bovis vivo (íntegro) e dos cisticercos mineralizados (mortos). Aspectos semelhantes são descritos na literatura (Costa et al. 2006). Entretanto, observou-se que havia dúvida para o diagnóstico e destino adequado de órgãos e carcaças quando os cistos estavam no estágio intermediário, ou seja, entre cistos vivos e mineralizados. Antes que os cisticercos estejam completamente mineralizados, eles invariavelmente passaram por fases ou etapas intermediárias (Jardim 2006). Com isso, após a correlação entre os achados macroscópicos e microscópicos, os cistos dessa fase intermediária foram classificados dentro do grupo degenerados com potencial escólex viável (Grupo 2). Os cisticercos desse grupo representam o maior desafio de diagnóstico no momento da inspeção e na consequente tomada de decisão do destino correto.

Os cistos degenerados com potencial escólex viável apresentaram dois aspectos morfológicos importantes e quando comparados entre eles, o segundo aspecto (Grupo $2 b$ ) deve ganhar maior destaque. Nesse padrão, observado em aproximadamente $30 \%$ dos casos do Grupo 2, a presença de um orifício na região central do cisto pode denotar a viabilidade do cisticerco. A análise histológica demonstrou que nove cistos (20\%) tinham a membrana parasitária viável e desses, um cisto apresentou além da membrana o escólex viável. A ausência do escólex nos casos em que foi observada apenas a membrana viável pode ser decorrente da inclusão no processamento apenas a vesícula do estágio larvar (Tessele et al. 2013). 0 primeiro padrão (Grupo 2a), visualizado em aproximadamente $70 \%$ dos cistos do Grupo 2, foi caracterizado macroscopicamente por cisticercos com predomínio de necrose caseosa, sem a presença do 
orifício na região central. As características microscópicas desse subgrupo designaram a perda da viabilidade infecciosa dos cistos, visto que praticamente não havia integridade das estruturas parasitárias em praticamente todos os casos analisados. Sugere-se que na rotina de inspeção os cisticercos sejam cortados transversalmente para avaliar o aspecto macroscópico do cisto e observar a presença de um orifício na região central. Esse achado é importante e auxilia na interpretação da viabilidade dos cistos, pois uma parcela de cisticercos do Grupo $2 \mathrm{~b}$ demonstrou estruturas parasitárias viáveis na análise histológica.

Nas seções histológicas de alguns cisticercos do Grupo 2 e Grupo 3, no qual não havia a membrana ou escólex degenerados da forma larvar, observaram-se características que podem auxiliar no diagnóstico de cisticercose, que incluíam infiltrado inflamatório de histiócitos dispostos em paliçada que circundavam a área necrótica ou mineralizada, infiltrado granulomatoso e de eosinófilos e a presença ocasional de corpúsculos calcários, caracterizados por estruturas ovais basofílicas. Esses aspectos microscópicos, principalmente, a observação dos corpúsculos calcários, asseguram o diagnóstico de cisticercose (Santos 1984, Costa et al. 2012, Tessele et al. 2013, Eberhard 2014). Considerando a escassez dos corpúsculos calcários deve-se atentar, pois algumas dessas estruturas podem apresentar-se como corpúsculos incolores ou ser confundidos com áreas de mineralização distrófica (Costa et al. 2012).

De acordo com o artigo 185 do RIISPOA (Brasil 2017), serão condenadas as carcaças com infestação intensa por C. bovis. Entende-se por infecção intensa quando são encontrados, pelo menos, oito cistos, viáveis ou calcificados, assim distribuídos: dois ou mais cistos localizados, simultaneamente, em pelo menos dois locais de eleição examinados na linha de inspeção (músculos da mastigação, língua, coração, diafragma e seus pilares, esôfago e fígado), totalizando pelo menos quatro cistos; e quatro ou mais cistos localizados no quarto dianteiro (músculos do pescoço, do peito e da paleta) ou no quarto traseiro (músculos do coxão, da alcatra e do lombo), após pesquisa no DIF, mediante incisões múltiplas e profundas. Quando forem encontrados mais de um cisto, viável ou calcificado, e menos do que o fixado para infecção intensa, considerando a pesquisa em todos os locais de eleição examinados na linha de inspeção e na carcaça correspondente, esta deve ser destinada ao aproveitamento condicional pelo uso do calor, após remoção e condenação das áreas atingidas. Quando for encontrado um cisto viável, considerando a pesquisa em todos os locais de eleição examinados na linha de inspeção e na carcaça correspondente, esta deve ser destinada ao tratamento condicional pelo frio ou pela salga, após a remoção e a condenação da área atingida. Quando for encontrado um único cisto já calcificado, considerando todos os locais de eleição examinados, rotineiramente, na linha de inspeção e na carcaça correspondente, esta pode ser destinada ao consumo humano direto sem restrições, após a remoção e a condenação da área atingida. 0 diafragma e seus pilares, 0 esôfago e o fígado, bem como outras partes passíveis de infecção, devem receber o mesmo destino dado à carcaça. No presente estudo, assim como também é descrito na litera- tura (Juranek et al. 1976, Rodrigues 1993, Costa et al. 2012, Rossi et al. 2014), observou-se que o mesmo bovino pode apresentar diferentes estágios dos cistos de $C$. bovis. Cabe ressaltar ainda, que a existência de um único cisticerco mineralizado não isenta a carcaça da presença de cisticercos vivos em locais que não sejam rotineiramente inspecionados (Juranek et al. 1976, Rodrigues 1993).

Dos 26 cisticercos, somente dois foram negativos quando avaliados pela PCR nesse estudo. Esse resultado pode estar relacionado ao fato desses cistos estarem mineralizados ou degenerados. Dados semelhantes foram observados em um trabalho realizado com cisticercos bovinos, que demonstrou uma queda na sensibilidade em amostras mineralizadas ou degeneradas quando submetidas à PCR, devido a redução na quantidade de DNA alvo (Cuttell et al. 2013). Embora ocorra a diminuição na sensibilidade, a PCR representa uma importante ferramenta que pode auxiliar no diagnóstico de cisticercose bovina, aliada ao exame macroscópico e histopatológico.

Alguns diagnósticos diferenciais de cisticercose bovina devem ser considerados. Dentre as principais alterações descritas destacam-se a actinobacilose, tuberculose, hidatidose e migrações de helmintos e trematódeos (principalmente Fasciola hepatica), que em alguns casos podem ser erráticas (Tortelly 2003, Costa et al. 2006, Costa et al. 2012). Entre essas condições, hidatidose, actinobacilose e migrações parasitárias, devem ganhar maior atenção como diferenciais e as características morfológicas são aspectos importantes na diferenciação.

$\mathrm{Na}$ etiopatogenia das lesões hepáticas, por exemplo, observa-se que é comum a migração ou encistamento de larvas de helmintos. Muitas vezes também é atribuída à hidatidose, a principal enfermidade implicada quando lesões hepáticas císticas ocorrem (Costa et al. 2012). Em um estudo realizado com fígados de bovinos abatidos em frigoríficos (Tortelly 2003), havia 183 lesões nodulares e 37 císticas suspeitas de hidatidose. A análise microscópica das lesões nodulares confirmou apenas dois casos de cito hidático. Em sete casos foram observados os corpúsculos calcários constituindo casos de cisticercose e os demais casos foram reputados como migração de larvas de helmintos inespecíficas. As 37 lesões císticas eram cistos congênitos.

\section{CONCLUSÕES}

Os resultados aqui apresentados demonstram que morfologicamente os cisticercos podem ser divididos em três grupos: cisticercos vivos (viáveis) (Grupo 1), cisticercos degenerados com potencial escólex viável (Grupo 2 [2a e 2b]) e cisticercos mineralizados (mortos) (Grupo 3).

A correlação entre os aspectos macroscópicos e microscópicos do segundo padrão morfológico observado dentro do Grupo 2 (Grupo 2b), demonstrou que esse subgrupo representa a maior problemática, pois um grande número de cistos apresentou características de viabilidade.

Macroscopicamente esses cisticercos podem ser identificados quando cortados transversalmente, porque possuem um orifício na área central que pode auxiliar no diagnóstico. 
O coração e o músculo masseter foram os principais locais anatômicos de predileção dos cistos de Cysticercus bovis. Além disso, a técnica da PCR demonstrou boa sensibilidade e pode auxiliar no diagnóstico de cisticercose bovina, aliada ao exame macroscópico e histopatológico. Entretanto, dependendo do estágio do cisticerco o resultado da PCR pode ser negativo.

\section{REFERÊNCIAS}

Biondi G.F., Henrique C.H., Oliveira A.C. \& Castro A.P. 2000. Avaliação da eficiência da prova de evaginação em metacestódeos de Taenia saginata. Revta Educ. Cont. CRMV.SP 3(1):49-54.

Borman-Eby H.A.C., Ayim D.S. \& Small C. 1994. Cysticercus bovis in cattle in two beef feedlots in southern Ontario. Can. Vet. J. 35:711-713.

Bowman D.D. 2014. Helminths, p.137-148. In: Ibid. (Ed.), Georgis' Parasitology for Veterinarians. 10th ed. Saunders Elsevier, Philadelphia. 477p.

Brasil 2017. Regulamento da Inspeção Industrial e Sanitária de Produtos de Origem Animal (Aprovado pelo decreto no 9.013, de 29.03.2017). RIISPOA, Ministério da Agricultura, Pecuária e Abastecimento, Brasília.

Bundza A., Finley G.G. \& Easton K.L. 1988. An outbreak of cisticercosis in feedlot cattle. Can. Vet. J. 29:993-996.

Cooper B.J. \& Valentine B.A. 2016. Muscle and tendon, p.239-240. In: Maxie M.G. (Ed.), Jubb, Kennedy, and Palmer's Pathology of Domestic Animals. Vol.1. 6th ed. Elsevier, St Louis. 798p.

Costa R.F.R., Santos I.F., Nascimento E.R. \& Tortelly R. 2006. Caracterização das reações inflamatórias em corações de bovinos comercializados na cidade de Nova Friburgo/RJ. Revta Bras. Ciênc. Vet. 13:76-79.

Costa R.F.R., Santos I.F., Santana A.P., Tortelly R., Nascimento E.R., Fukuda R.T., Carvalho E.C.Q. \& Menezes R.C. 2012. Caracterização das lesões por Cysticercus bovis, na inspeção post mortem de bovinos, pelos exames macroscópico, histopatológico e pela reação em cadeia da polimerase (PCR). Pesq. Vet. Bras. 32(6):477-484.

Cuttell L., Owena H., Lew-Taborb A.E. \& Trauba R.J. 2013. Bovine cysticercosis-Development of a real-time PCR to enhance classification of suspect cysts identified at meat inspection. Vet. Parasitol. 194:65-69.

Eberhard M.L. 2014. Histopathologic Diagnosis, p.412-416. In: Ibid. (Ed.),
Georgis' Parasitology for Veterinarians. 10th ed. Saunders Elsevier, Philadelphia. 477p.

Jardim E.A.G.V. 2006. Anátomo-histopatologia e PCR na identificação de cisticercos de bovinos. Tese de Doutorado, Escola de Veterinária, Universidade Federal de Goiás, Goiânia. 79p.

Juranek D.D., Forbes L.S. \& Keller U. 1976. Taenia saginata cysticerci in muscles of beef cattle. Am. J. Vet. Res. 37(7):785-789.

Maxie M.G. \& Robinson W.F. 2007. Cardiovascular system, p.42-43. In: Maxie M.G. (Ed.), Jubb, Kennedy, and Palmer's Pathology of Domestic Animals. Vol.3. 5th ed. Saunders Elsevier, Philadelphia. 737p.

McAninch N.H. 1974. An outbreak of cysticercosis in feedlot cattle. Can. Vet. J. 15(4):120-122.

Narankhajid M., Bolormaa V., Sayamaa S., Ito A., Yamasaki H., Sugar L. \& Abmed A. 2007. Specific detection of Taenia saginata eggs by PCR. IFMBE Proceedings 14(1):225-228.

Pfuetzenreiter M.R. \& Ávila-Pires F.D. 2000. Epidemiologia da teníase/cisticercose por Taenia solium e Taenia saginata. Ciênc. Rural 30(3):541548.

Rey L. 2013. Parasitologia: parasitos e doenças parasitárias do homem nos trópicos ocidentais. 4⿳a ed. Guanabara Koogan, Rio de Janeiro.

Rodrigues L.V.C. 1993. Inspeção sanitária e critério de julgamento da cisticercose bovina calcificada. Infecção leve. Ciência Rural. 23(3):339-344.

Rossi G.A.M., Grisólio A.P.R., Prata L.F., Bürger K.P. \& Hoppe E.G.L. 2014. Situação da cisticercose bovina no Brasil. Semina, Ciênc. Agrárias 35(2):927-938.

Santos I.F. 1984. Diagnóstico da cisticercose bovina em matadouros: novas técnicas de exame de esôfago e diafragma. Tese de Doutorado, Faculdade de Veterinária, Universidade Federal Fluminense, Niterói, RJ. 127p.

Tessele B., Brum J.S. \& Barros C.S.L. 2013. Lesões parasitárias encontradas em bovinos abatidos para consumo humano. Pesq. Vet. Bras. 33(7):873889.

Tortelly R. 2003. Lesões em fígados de bovinos sob Inspeção Sanitária e sua importância em Saúde Pública. Tese de Doutorado, Instituto de Veterinária, Universidade Federal Rural do Rio de Janeiro, Seropédica. 95p.

Urquhart G.M., Armour J., Duncan J.L., Dunn A.M. \& Jennings F.W. 1996. Classe cestoda, p.104-110. In: Ibid. (Eds), Parasitologia Veterinária. $2^{\underline{a}}$ ed. Guanabara Koogan, Rio de janeiro. 273p. 